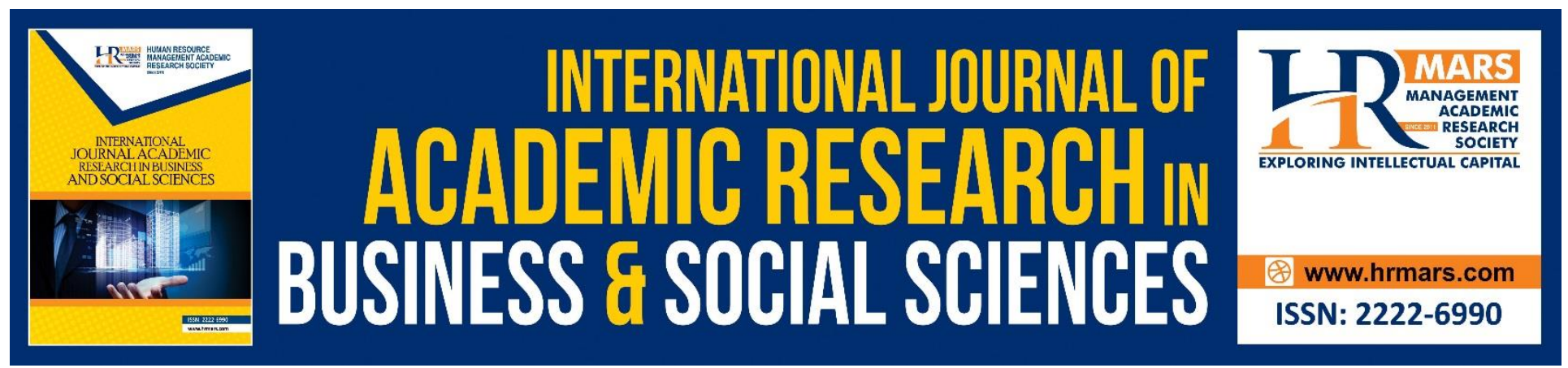

\title{
Relationship between Mathematics Diagnostic Test and Mathematics Final Assessment Among Pre-University Students Based on Gender
}

Farah Liyana Azizan \& George Tan Geok Shim

To Link this Article: http://dx.doi.org/10.6007/IJARBSS/v11-i14/8563

DOI:10.6007/IJARBSS/v11-i14/8563

Received: 16 November 2020, Revised: 14 December 2020, Accepted: 02 January 2021

Published Online: 30 January 2021

In-Text Citation: (Azizan \& Shim, 2021)

To Cite this Article: Azizan, F. L., \& Shim, G. T. G. (2021). Relationship between Mathematics Diagnostic Test and Mathematics Final Assessment Among Pre-University Students Based on Gender. International Journal of Academic Research in Business and Social Sciences, 11(14), 182-190.

\section{Copyright: (c) 2021 The Author(s)}

Published by Human Resource Management Academic Research Society (www.hrmars.com)

This article is published under the Creative Commons Attribution (CC BY 4.0) license. Anyone may reproduce, distribute, translate and create derivative works of this article (for both commercial and non-commercial purposes), subject to full attribution to the original publication and authors. The full terms of this license may be seen at: http://creativecommons.org/licences/by/4.0/legalcode

Special Issue: Contemporary Business and Humanities Landscape Towards Sustainability, 2021, Pg. 182 - 190

Full Terms \& Conditions of access and use can be found at http://hrmars.com/index.php/pages/detail/publication-ethics 


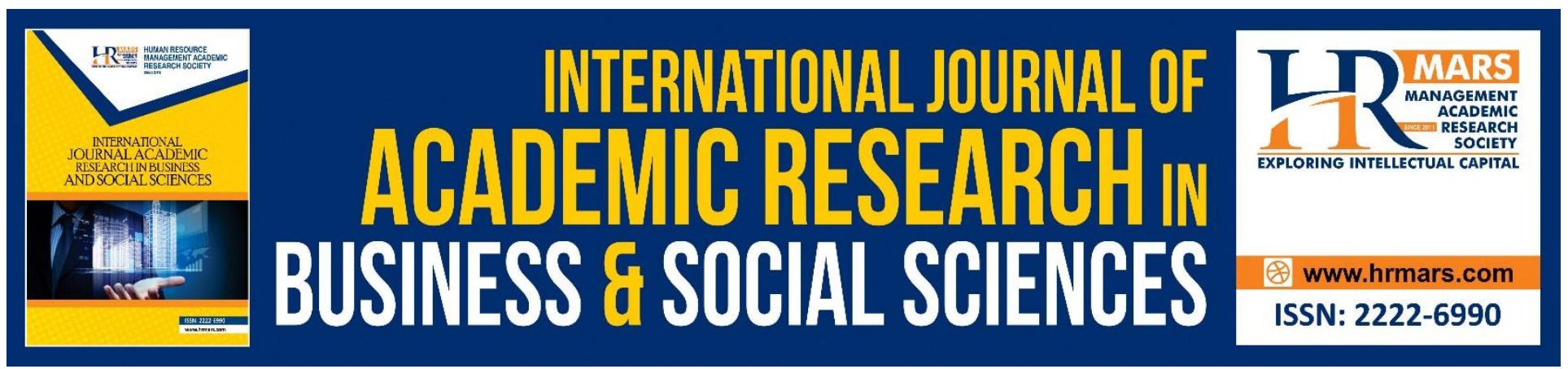

\title{
Relationship between Mathematics Diagnostic Test and Mathematics Final Assessment Among Pre- University Students Based on Gender
}

\author{
Farah Liyana Azizan \& George Tan Geok Shim \\ Centre for Pre-University Studies, Universiti, Malaysia Sarawak, 94300, Kota Samarahan, Sarawak, \\ Malaysia \\ Email: afliyana@unimas.my
}

\begin{abstract}
Diagnostic testing is considered as an important device that can be used by educators to identify students' strong and weak points in Mathematics subjects as it is often used as a preliminary evaluation of basic Mathematics skills of students. Educators must be able to detect the students' mathematical capacity earlier before delivering new content to them. This article purposes are to identify the achievement of pre-university students in Mathematics diagnostic test and Mathematics final assessment based on their gender, the differences between the gender of the students with their achievement in Mathematics diagnostic test, and the correlation between the students' Mathematics diagnostic test and their achievement in pre-university Mathematics final assessment. The findings demonstrated that students of both genders, who accomplished good results in their Mathematics diagnostic test, did similarly good in their final assessment. Also, students who carried out badly in their Mathematics diagnostic test did poorly in their final assessment. From this diagnostic result, it facilitates the educator to provide the students with the best teaching method and material required.
\end{abstract}

Keywords: Diagnostic Test, Final Assessment, Gender, Mathematics, Pre-University

\section{Introduction}

Mathematics mastery plays a vital role alongside the present focus of Science, Technology, Engineering and Mathematics (STEM) education as competence in mathematics will significantly supplement the processes of learning and mastery of various fields of Science that include Biotechnology, Engineering, and Physics. It has also been supported by Otung (2001) who claimed that Mathematics is a crucial instrument in engineering as models that employ mathematical parameters and applicable laws for engineering structure and system analysis and design. Moreover, the way toward creating equations in Science involves Mathematics too in deciding the estimation of 
unknown parameters and geometry concerning property derivation, estimation, just as the association of points, angles, figures, and lines in space (Swaranjit, 2015).

Mathematics is vital in higher education as the application of mathematical concepts is necessary for the pedagogy of most of the courses. Moreover, it has been reported that Mathematics mastery serves as a significant indicator of students' general academic accomplishments at the university (Tang et al., 2009). Moreover, the achievement of many first-year undergraduates was hindered mainly due to their inadequacy of confidence and capability in Mathematics (Gillard et al., 2010). Therefore, it can be deduced that a firm grasp and foundation in Mathematics are crucial for university students, especially the first years, as it will assist them to excel in studies.

A rise in student enrolment at higher education institutions has been recorded for the past few years in many countries, including Malaysia. Although this increment is a positive phenomenon, it has simultaneously posed a challenge for many lecturers. The variation which occurs within each cohort of students can be attributed to the increased accessibility to university education as well as the different range of curricula and syllabi used at school (Batchelor, 2004). Before teaching new contents in the course, educators need to formulate relevant techniques to identify their students' mathematical aptitude at an early stage so that the discrepancies in students' educational backgrounds can be addressed effectively. Also, students who face difficulties in Mathematics can be assisted through early recognition of limitations in their mathematical skills, such that intervention or remedial instruction can be conducted by educators to ensure a smooth learning process in the course. Diagnostic testing is one of the devices that is employed by educators to accommodate this situation.

This paper describes a study carried out by a local public university which mainly utilised a Mathematics course at the foundation level to analyse the connection between the students' results in the Mathematical diagnostic test and their achievement in the final assessment. As such, this paper lists the objectives by identifying the student's performance for Mathematics diagnostic test and preuniversity final Mathematics assessment based on their gender, the difference between student's gender and their achievement in Mathematics diagnostic test, and the connection between student's Mathematics diagnostic test and their results in pre-university Mathematics final assessment.

\section{What is Mathematics diagnostic testing?}

"Diagnosis" as a term that refers to a thorough analysis of a subject to ascertain its nature, and this term is typically used in the medical field (Carpenito-Moyet, 2007). Nevertheless, according to Ketterlin-Geller and Yovanoff (2009), diagnosis is described in education based on an instructional approach in which details regarding students' proficiency of related existing skills and knowledge in the domain, in addition to misconceptions or preconceptions of the contents are provided using assessment. Thus, it is also implied that diagnostic test acts as an assessment mainly dedicated to recognising both strong and weak points of students in any courses or subjects (Zhao, 2013).

Furthermore, a diagnostic test is an immediate impact on the alleged decline in the students' mathematical skills and knowledge concerning the mathematical prerequisites of their university programmes (Appleby et al., 2000). Moreover, Learning and Teaching Support Network (LTSN) Maths TEAM (2003) has reported that diagnostic assessments involving intelligent diagnostic systems or computer-generated multiple-choice questions and a simple paper-based test are typically used during the first few weeks at the start of the semester or in the induction week. 
INTERNATIONAL JOURNAL OF ACADEMIC RESEARCH IN BUSINESS AND SOCIAL SCIENCES

Vol. 11, No. 14, Contemporary Business and Humanities Landscape Towards Sustainability. 2021, E-ISSN: 2222-6990 @ 2021 HRMARS

\section{Advantages of Applying Diagnostic Analyses in Mathematics}

Through the help of diagnostic analyses, students' needs, and activities can be considered by the universities when designing the instructional approaches to Mathematics pedagogy. Additionally, the results of diagnostic assessments can be advantageous to subject lecturers since they can immediately identify the overall competency of a cohort of students regarding their basic mathematical skills. It also serves as an instrument that effectively provides the information of disparities in the type or level of knowledge that an individual student should already acquire, as well as performing the relevant remedial intervention (Sheridan, 2012; Andronnikova, 2014).

Students' competency in mathematical areas such as algebra and arithmetic has been improved through diagnostic evaluations (Sheridan, 2012). Another study has also discovered that students' grades in the California Standards Test (CST) Mathematics test was enhanced by the Mathematics Diagnostic Testing Project (MDTP) (Betts et al., 2011). Also, by inspecting the impact of diagnostic evaluation on a first-year Mathematics course, Carmody, Godfrey, and Wood (2012) determined a constructive relationship between the Mathematics diagnostic evaluation and students' achievements in their final assessment. Additionally, recent research also demonstrated similar findings when the students' Mathematics diagnostic test was compared to their final examination at the foundation level (Tan et al., 2017). Batchelor (2004) has also reported that a diagnostic test can deliver a quick evaluation of the knowledge base in addition to prompt support in Mathematics for both educators and students.

\section{Methodology}

This research adopted the inquisition technique to gather data in an attempt to discover the gender differences between students' Mathematics diagnostic test with their performance in the preuniversity Mathematics subject. The participants were selected at random from students who enrolled at a public university at a pre-university programme. Five hundred $(N=500)$ students had been chosen to be the participants with two hundred and fifty male and female each.

In this exploration, data were driven from a Mathematic diagnostic test and students' final assessment in Mathematics subject, which functioned as the research instruments. It is worth noticing that for the purpose of ensuring the students' readiness and existing knowledge regarding the foundation Mathematics courses offered by the local university, the diagnostic test was structured by the foundation programme educators themselves. The test consisted of eight calculation questions concerning the basic mathematical concepts like calculus and algebra (differentiation and integration). Students' demographic details, including gender and results of Mathematics and Additional Mathematics in Sijil Pelajaran Malaysia (SPM), were also collected.

The research took place during the length of one semester of pre-university studies in 2 phases. At the start of semester 1, students were presented with the Mathematics diagnostic test and must complete the test in an hour. It must be highlighted that the outcome of the diagnostic test was not used in any way to influence the pedagogic structure of the pre-university Mathematics subject. This step was taken to preserve fair and equal treatment towards all students about their learning experience.

In the second phase, the students' final assessment results in the Mathematics subject were obtained at the end of the semester. To assess the data gathered by the Mathematics diagnostic test and pre-university Mathematics final assessment results, the Statistical Package for the Social Science 
(SPSS) adaptation 23.0 programming was utilised. Meanwhile, to assess the students' demographic data, descriptive statistics were utilised. Inferential statistics applying Pearson Moment correlation was used to find the connection between students' Mathematics diagnostic test and their Mathematics' accomplishment at the foundation level.

\section{Results and Discussion}

In analysing the data, the students' demographic information, for example, their gender, their SPM results for Mathematics and Additional Mathematics, their achievements in Mathematics diagnostic test and their pre-university final assessment results, the prevalence of gender differences in Mathematics diagnostic test, including the connection between the students' Mathematics diagnostic test and pre-university Mathematics assessment for both genders. In order to ascertain the students' achievements in their Mathematics diagnostic test and pre-university Mathematics final assessment, descriptive analysis was conducted. Meanwhile, the integration of statistical analysis into the inferential statistics was done to uncover the relationships and trends among the research variables according to the developed hypotheses.

Table 1 Students' SPM Mathematics results

\begin{tabular}{|c|c|c|c|c|}
\hline & \multicolumn{2}{|c|}{ Male } & \multicolumn{2}{|c|}{ Female } \\
\hline & Number $(\mathrm{N})$ & Percentage (\%) & Number (N) & Percentage (\%) \\
\hline$A+$ & 120 & 48.0 & 120 & 48.0 \\
\hline$A$ & 119 & 47.6 & 125 & 50.0 \\
\hline A- & 11 & 4.4 & 4 & 1.6 \\
\hline $\mathrm{B}$ & - & - & 1 & 0.4 \\
\hline TOTAL & 250 & 100.0 & 250 & 100.0 \\
\hline
\end{tabular}

Table 1 displays students' SPM Mathematics results according to gender. A total of five hundred $(N=$ $500)$ students were selected, in which they were equally divided to represent male and female. Table 1 further depicts that a majority of the respondents obtained A+ and A in their SPM Mathematics results with $95.6 \%$ and $98 \%$ in total respectively for male and female. Only $4.4 \%$ got A-for males. Meanwhile, for females, only $1.6 \%$ obtained $\mathrm{A}$ - and $0.4 \%$ received $\mathrm{B}$.

Table 2 Students' SPM Additional Mathematics results

\begin{tabular}{ccccc}
\hline \multicolumn{4}{c}{ Male } & \multicolumn{2}{c}{ Female } \\
\hline & Number (N) & Percentage (\%) & Number (N) & Percentage (\%) \\
\hline A+ & 19 & 7.6 & 10 & 4.0 \\
A & 45 & 18.0 & 50 & 20.0 \\
A- & 45 & 18.0 & 44 & 17.6 \\
B+ & 60 & 24.0 & 81 & 32.4 \\
B & 49 & 19.6 & 48 & 19.2 \\
C & 29 & 11.6 & 17 & 6.8 \\
C & 3 & 1.2 & - & - \\
\hline TOTAL & 250 & 100.0 & 250 & 100.0 \\
\hline
\end{tabular}


Table 2 displays students' SPM Additional Mathematics results according to gender. The table exhibits that male and female students mainly achieved $B+$ with $24 \%$ and $32.4 \%$ accordingly. For male, the results are as follows, $7.6 \%$ obtained $A+, 18 \%$ got $A, 18 \%$ obtained $A-, 19.6 \%$ obtained $B, 11.6 \%$ received $C+$ and $1.2 \%$ obtained $C$. For female, the results are $4.0 \%$ got $A+, 20 \%$ obtained $A, 17.6 \%$ obtained $A-, 19.2 \%$ obtained $B$ and $6.8 \%$ obtained $C+$. The next section discusses the results obtained in conjunction with the objectives outlined in this study.

Objective 1: Identifying students' performance for Mathematics diagnostic test and Pre-University Mathematics final assessment according to gender.

Table 3 The mean and standard deviation of Mathematics diagnostic test based on gender

\begin{tabular}{ccccc}
\hline & & Mean & Standard Deviation & $\mathrm{N}$ \\
\hline Mathematics Diagnostic & Male & 78.93 & 12.318 & 250 \\
Test & Female & 81.89 & 11.216 & 250 \\
\hline & & Total & 500 \\
\hline
\end{tabular}

Table 4 The mean and standard deviation of Pre-University Mathematics final assessment based on gender

\begin{tabular}{ccccc}
\hline & & Mean & Standard Deviation & $\mathrm{N}$ \\
\hline $\begin{array}{c}\text { Pre-University } \\
\begin{array}{c}\text { Mathematics Final } \\
\text { assessment }\end{array}\end{array}$ & Male & 67.48 & 15.001 & 250 \\
& Female & 75.72 & 11.190 & 250 \\
\hline
\end{tabular}

Table 3 and 4 display the mean and standard deviation for Mathematics diagnostic test and PreUniversity Mathematics final assessment according to the students' gender. For Mathematics diagnostic test, female results are higher than the male with mean value 81.89 for female 78.93 for male. As well as Pre-University Mathematics final assessment, female scored higher compared to male with mean value 75.72 and 67.48 respectively.

Objective 2: The difference between students' gender and their performance in Mathematics diagnostic test.

Table 5 Gender differences in Mathematics diagnostic test

\begin{tabular}{ccccccc}
\hline & $\mathrm{N}$ & Mean & s.d & $t$ & $d f$ & Sig \\
\hline Mathematic Diagnostic test & & & & -2.805 & 498 & 0.05 \\
Male & 250 & 78.93 & 12.318 & & & \\
Female & 250 & 81.89 & 11.216 & & & \\
Total & 500 & & & & & \\
\hline
\end{tabular}

Table 5 presents the independent sample t-test based on the different gender achievement of the Mathematics diagnostic test. Based on the table, there is a significant difference between the gender for diagnostic test results $(t=-2.805, p \leq 0.05)$. The result shows that the students' achievement in the diagnostic test is affected by their gender too. 
INTERNATIONAL JOURNAL OF ACADEMIC RESEARCH IN BUSINESS AND SOCIAL SCIENCES

Vol. 11, No. 14, Contemporary Business and Humanities Landscape Towards Sustainability. 2021, E-ISSN: 2222-6990 @ 2021 HRMARS

Objective 3: The relationship between student's Mathematics diagnostic test and their performance in Pre-University Mathematics final assessment.

Table 6 Correlation between students' Mathematics diagnostic test and Pre-University Mathematics final assessment for male

\begin{tabular}{|c|c|c|c|}
\hline & & $\mathrm{N}$ & $\begin{array}{l}\text { Mathematics } \\
\text { Diagnostic test }\end{array}$ \\
\hline \multirow{3}{*}{\multicolumn{2}{|c|}{$\begin{array}{c}\text { Pre-University Mathematics final } \\
\text { assessment (male) }\end{array}$}} & Pearson correlation & $.443 * *$ \\
\hline & & Sig (2-tailed) & 0.00 \\
\hline & & $\mathrm{N}$ & 250 \\
\hline \multicolumn{4}{|c|}{ *Correlation is significant at the 0.01 level (2-tailed) } \\
\hline \multirow{2}{*}{\multicolumn{2}{|c|}{$\begin{aligned} \text { Table } 7 & \text { Correlation between student } \\
& \text { Mathematics final assessmer }\end{aligned}$}} & $\begin{array}{l}\text { matics diagnostic test } \\
\text { ale }\end{array}$ & e-University \\
\hline & & $\mathrm{N}$ & $\begin{array}{c}\text { Mathematics } \\
\text { Diagnostic test }\end{array}$ \\
\hline \multirow{3}{*}{\multicolumn{2}{|c|}{$\begin{array}{c}\text { Pre-University Mathematics final } \\
\text { assessment (female) }\end{array}$}} & Pearson correlation & $.295^{* *}$ \\
\hline & & Sig (2-tailed) & 0.00 \\
\hline & & $\mathrm{N}$ & 250 \\
\hline
\end{tabular}

***Correlation is significant at the 0.01 level (2-tailed)

The research continued with correlation analysis. Tables 6 and 7 present the relationships between students' Mathematics diagnostic test and pre-university Mathematics final assessment for both genders. Table 6 shows the correlation between male students. Regarding the table, a positive correlation between students' Mathematics diagnostic test and pre-university Mathematics final assessment was discovered with $r=0.443, p \leq 0.01$. A similar positive trend was found between students' Mathematics diagnostic test and pre-university Mathematics final assessment among the females with, $r=0.295, p \leq 0.01$.

From this study, the results showed that students will perform well in their Mathematics final assessments if the performance of their diagnostic test also showed well. Similarly, students who did not perform well in their diagnostic test got poor results in their final assessment. Overall, their performance in the study was affected by students' prior knowledge in Mathematics. From the finding of the diagnostic test, students with an inadequate basic understanding of Mathematics had difficulty coping with the new pre-university level programme offered. Most of the curriculum for Mathematics in pre-university level requires basic mathematical knowledge (modern Mathematics and Additional Mathematics) in secondary schools as its requirement for the subject matter. From the diagnostic test also, educators can distinguish the level of students' basic knowledge before teaching them the new content. This study also benefits the educators to plan intervention strategies in their teaching method to fit the current state of knowledge of their students in the class. Diagnostic testing is a helpful instrument for educators in learning subjects like Mathematics to detect the strength and weakness of the students. From this outcome, educators will be able to see the potential 
use and benefits of diagnostic testing in teaching and learning and utilise it at the start of every university course.

\section{Conclusion}

In conclusion, diagnostic testing is considered an excellent instrument that academicians can utilise to determine students' strengths and weaknesses in the courses they take like Mathematics. The research findings have shown that both male and female students who did well in their diagnostic test also did the same in their Mathematics final assessments. The results of the current research should be able to demonstrate the promising potential of diagnostic testing in pedagogy, thus influencing educators to employ the test at the start of university courses. For that matter, future work must infuse appropriate techniques in determining numerous kinds of weaknesses that students may experience before undergoing the pre-university Mathematics course. Additionally, other future work that can take into account is to identified remedial intervention strategies to instil academic excellence among students as a whole.

\section{References}

Andronnikova, O. (2014). Psycho Educational Conditions of the Development of Safe and Remediation of Dangerous Behaviors of a Child. International Journal of Academic Research in Psychology, 1(1), 32-40.

Appleby, J., Lawson, D., Croft, T., Hawkes, T., Douglas, Q., \& Sleeman, B. (2000). Diagnostic testing in theory and practice. Measuring the Mathematics problem. Retrieved from http://www.engc.org.uk/engcdocuments/internet/Website/Measuring\%20the\%20Mathemati c\%20Problems.pdf

Batchelor, H. (2004). The importance of a Mathematics diagnostic test for incoming pharmacy undergraduates. Pharmacy Education, 4(2), 69-74. https://doi.org/10.1080/15602210410001715626

Betts, J. R., Hahn, Y., \& Zau, A. C. (2011). Does diagnostic math testing improve student learning? Retrieved from http://www.ppic.org/content/pubs/report/R_1011JBR.pdf

Carmody, G., Godfrey, S., \& Wood, L. (2006). Diagnostic tests in a first-year Mathematics subject. Paper presented at the Proceedings of the Australian Conference on Science and Mathematics Education (formerly UniServe Science Conference). Retrieved from http://citeseerx.ist.psu.edu/viewdoc/download?doi=10.1.1.548.5597\&rep=rep1\&type=pdf

Carpenito-Moyet, L. J. (2007). Nursing diagnosis: Application to clinical practice (14th ed.). Philadelphia, PA: Lippincott.

Gillard, J., Levi, M., \& Wilson, R. (2010). Diagnostic testing at UK universities: An email survey. Teaching Mathematics and its Application. 29(2), 51-63. https://doi.org/10.1093/teamat/hrq004

Ketterlin-Gelle, L. R., \& Yovanoff, P. (2009). Diagnostic assessments in Mathematics to support instructional decision making. Practical Assessment, Research \& Evaluation, 14(16), 1-11. https://doi.org/10.7275/vxrk-3190

Learning and Teaching Support Network (LTSN) Maths TEAM. (2003). Diagnostic Testing for Mathematics. LTSN MathsTEAM Project. 
Otung, I. E. (2001). Reassessing the Mathematics content of engineering education. Engineering Science and Education Journal, 10(4), 130-138. http://doi.org/10.1049/esej:20010401

Sheridan, B. (2012). How much do our incoming first-year students know?: Diagnostic testing in Mathematics at third level. Teaching Fellowship, 24, 40-45. https://doi.org/10.21427/D7TX4G

Kaur, S. (2015). Application of Mathematics in sciences. International Journal of IT, Engineering and Applied Sciences Research, 4(6), 83-85.

Tan, G. G. S., Shakawi, A. M. A. H., \& Azizan, F. L. (2017). Relationship between Students' Diagnostic Assessment and Achievement in a Pre-University Mathematics Course. Journal of Education and Learning, 6(4), 364-371. https://doi.org/10.5539/jel.v6n4p364

Tang, H. E., Voon, L. L., \& Julaihi, N. H. (2009). A case study of 'High-Failure Rate' Mathematics courses and its' contributing factors on UiTM Sarawak diploma students. Paper presented at the Conference on Scientific \& Social Research. (14-15 March 2009).

Zhao, Z. (2013). An overview of studies on diagnostic testing and its implication for the development of diagnostic speaking test. International Journal of English Linguistics, 3(1), 41-45. http://dx.doi.org/10.5539/ijel.v3n1p41 